\title{
The Coptotermes gestroi
}

\section{aldo-keto reductase: a multipurpose enzyme for biorefinery applications}

\author{
Robson Tramontina 1,2, João Paulo L. Franco Cairo ${ }^{1}$, Marcelo V. Liberato' ${ }^{1}$, Fernanda Mandelli' , Amanda Sousa ${ }^{1,2}$, \\ Samantha Santos ${ }^{1}$, Sarita Cândida Rabelo', Bruna Campos³, Jaciane lenczak', Roberto Ruller', \\ André R. L. Damásio ${ }^{4}$ and Fabio Marcio Squina ${ }^{1 *}$
}

\begin{abstract}
Background: In nature, termites can be considered as a model biological system for biofuel research based on their remarkable efficiency for lignocellulosic biomass conversion. Redox enzymes are of interest in second-generation ethanol production because they promote synergic enzymatic activity with classical hydrolases for lignocellulose saccharification and inactivate fermentation inhibitory compounds produced after lignocellulose pretreatment steps.

Results: In the present study, the biochemical and structural characteristics of the Coptotermes gestroi aldo-keto reductase (CgAKR-1) were comprehensively investigated. CgAKR-1 displayed major structural differences compared with others AKRs, including the differences in the amino acid composition of the substrate-binding site, providing basis for classification as a founding member of a new AKR subfamily (family AKR1 I). Immunolocalization assays with anti-CgAKR-1 antibodies resulted in strong fluorescence in the salivary gland, proventriculus, and foregut. CgAKR-1 supplementation caused a $32 \%$ reduction in phenolic aldehydes, such as furfural, which act as fermentation inhibitors of hemicellulosic hydrolysates, and improved ethanol fermentation by the xylose-fermenting yeast Scheffersomyces stipitis by 45\%. We observed synergistic enzymatic interactions between CgAKR-1 and commercial cellulosic cocktail for sugarcane bagasse saccharification, with a maximum synergism degree of 2.17 for sugar release. Our data indicated that additive enzymatic activity could be mediated by reactive oxygen species because CgAKR-1 could produce hydrogen peroxide.

Conclusion: In summary, we identified the founding member of an AKRI subfamily with a potential role in the termite digestome. CgAKR-1 was found to be a multipurpose enzyme with potential biotechnological applications. The present work provided a basis for the development and application of integrative and multipurpose enzymes in the bioethanol production chain.
\end{abstract}

Keywords: Coptotermes gestroi, Aldo-keto reductase, Bioethanol, Detoxification, Reactive oxygen species

\section{Background}

Lignocellulose is a recalcitrant matrix composed of cellulose, hemicelluloses, and lignin, and a complex set of enzymes are required for the efficient conversion of these plant cell wall polymers into fermentable sugars

\footnotetext{
*Correspondence: fabio.squina@gmail.com

${ }^{1}$ Laboratório Nacional de Ciência e Tecnologia do Bioetanol (CTBE),

Centro Nacional de Pesquisa em Energia e Materiais (CNPEM), Rua

Giuseppe Máximo Scolfaro, no 10000 Campinas, SP, Brazil

Full list of author information is available at the end of the article
}

[1]. Termites can degrade almost $90 \%$ of consumed plant biomass and can provide an excellent biological system for studying the biochemical depolymerization of lignocellulosic biomass [2,3]. The gut of Coptotermes gestro $i$ (Rhinotermitidae) and other termites has specialized adaptations to digest lignocellulosic diets [4]. In the termite gut, carbohydrate-active enzymes (CAZymes), such as cellulases and hemicellulases, are secreted (i.e., both symbiotic and endogenous enzymes). Additionally, a set of pro-oxidant, antioxidant, and detoxification 
enzymes (PADs) is also present [5-7]. Among the PADs found in termites, superoxide dismutase (SOD), catalases (CATs), glutathione S-transferase (GST), and aldo-keto reductases (AKRs) have been studied in detail because the transcription of mRNAs encoding these enzymes is upregulated in response to lignocellulose degradation [8].

One of the major bottlenecks for second-generation ethanol production is the toxic metabolites produced after lignocellulose pretreatment [9]. Different lignocellulose pretreatments, such as diluted acids, are required to minimize biomass recalcitrance, alter the biomass structure, and enhance the enzymatic degradation of lignocellulose [10]. However, during lignocellulosic biomass pretreatment, several chemical by-products are generated, which inhibit fermentative microorganisms and lignocellulolytic enzymes [11]. These chemicals include aldehydes, aliphatic acids, furan derivatives, and phenolic compounds, such as hydroxybenzoic acid, furfural, and hydroxymethylfurfural (HMF) [9, 12, 13]. For example, the presence of furfural can strongly inhibit the growth of many yeast strains by cell wall and membrane damage, enzymatic activity inhibition, DNA damage, and protein and RNA synthesis $[13,14]$.

Physicochemical and biological strategies are being developed to minimize the effects of these inhibitors on enzymatic and microbial activity for second-generation ethanol [11]. Recently, Liu et al. [15] highlighted the importance of developing an easy-to-handle in situ detoxification method combined with a fermentation process in order to produce second-generation ethanol from low-cost lignocellulosic biomass. However, with the exception of microbial laccases and peroxidases, such products have not been reported frequently [10]. Therefore, PADs and related enzymes may have many applications in the detoxification of lignocellulosic hydrolysates $[8,11,16,17]$.

Studies of the oxidoreductive mechanisms that can improve lignocellulose biomass saccharification have shown that laccases, peroxidases, and other auxiliary redox activities enzymes can enhance biomass hydrolysis by acting on the recalcitrance of woody materials by direct or indirect oxidation of holocellulose [18-20].

The involvement of redox enzymes in lignocellulose modification and degradation in the termite digestome has not been fully elucidated [2, 7, 21-23]. Previous studies suggested that enzymes related to redox reactions and detoxifying metabolism may improve the ability of termites to digest a lignocellulosic diet. For example, hydrogen peroxide and reduced iron were found in the guts of Coptotermes formosanus and Zootermopsis nevadensis, respectively, in acidic $\mathrm{pH}$ conditions [2, 22, 24]. These results suggested that highly reactive radicals were generated in the termite gut $[24,25]$.
Franco Cairo et al. [26] showed that AKR transcripts from the termite Coptotermes gestroi were abundant in worker castes (responsible for colony feeding [27].) The AKR superfamily of proteins is known to catalyze the $\mathrm{NAD}[\mathrm{P}] \mathrm{H}$-dependent reduction of various carbonylcontaining compounds to their corresponding alcohols, and systematic nomenclature for the AKR superfamily has been in place since 1996 (www.med.upenn.edu/akr) [28]. Moreover, AKRs are involved in several metabolic reactions in different organisms, including carbohydrate degradation, xenobiotic detoxification, degradation of $\beta$-aryl ethers in lignin, and various industrial and clinical applications [29-31].

In this work, we describe the AKR from the termite C. gestroi (CgAKR-1), a founding member of a new AKR subfamily of potential biotechnological interest. To the best of our knowledge, this is the first report in the literature to describe the use of AKR for detoxification of fermentation inhibitors during C5 ethanol fermentation. Furthermore, this work provides a basis for studies of the synergistic enzymatic interactions of AKRs with cellulases and the use of multipurpose enzymes for bioprocess integration aiming to improve lignocellulosic biorefinery performance.

\section{Results and discussion \\ CgAKR-1 was a founding member of a new AKR1I subfamily}

Recently, several research groups have investigated the termite digestome, hypothesizing that auxiliary redox mechanisms may be involved in lignocellulose degradation [5, 26, 27, 32-34]. Among these studies, Scharf and Sethi [27] reported that an AKR acted synergically with termite and symbiotic GHs during pine wood hydrolysis. $A K R$ transcripts were recently found to be abundantly expressed in C. gestroi worker castes when consuming a diet based on pinewood, suggesting that some AKRs from C. gestroi are highly expressed in response to lignocellulosic material. However, few details of the biochemical and structural properties of termite AKR have been reported [27].

The predicted open reading frame (ORF) of CGAKR1, based on genomic data, contained 334 amino acids (GenBank accession number: KU686221). The domain architecture evaluation performed by comparison of the CgAKR-1 protein sequence with the PFAM database indicated the presence of a conserved domain from the AKR superfamily. Moreover, a comparison of the predicted protein $C g \mathrm{AKR}-1$ with the NCBI database indicated higher similarity to a protein from $C$. formosanus (97\% identity, accession number AGM32584.1 [1AKR]). According to data from the AKR superfamily homepage, AKRs are found in both prokaryotes and eukaryotes and 
are distributed among 16 families [35]. A phylogenetic tree was constructed using the amino acid sequence from all 16 AKR family members, in which CgAKR-1 was located in family 1 (Additional file 1: Figure S1). Subsequently, another phylogenetic tree was constructed using the amino acid sequence of AKRs from family 1 only, and CgAKR-1 was clustered in an unaffiliated clade and classified as a novel AKR subfamily (Fig. 1). According to the nomenclature specifications, CgAKR-1 was a founding member of the new subfamily "AKR1 I" [35]. The most related and well-characterized family members in this database are human AKR (AKR1A1) and nematode AKR from Caenorhabditis elegans (AKR1G1) [35]. Generally, members of the AKR1 family have broad specificity for aldehydes, are cytosolic and monomeric proteins, and interact strongly with NADPH as a cofactor [30, 35].

The gene-encoding CgAKR-1 was successfully cloned in Escherichia coli ArcticExpress DE3 competent cells, and the soluble enzyme was purified by affinity and size exclusion chromatography steps with high enzyme yield ( $25 \mathrm{mg} / \mathrm{L}$ of cell culture; see Additional file 1: Figure S2).

\section{CgAKR-1 was primarily localized in the termite foregut region}

The detection of nonsymbiotic phenoloxidase activities in termites has already been described, supporting the oxidative degradation of lignin and cellulose in the gut of termites [3,33]. However, elucidation of the redox mechanisms in the termite digestome is necessary. Accordingly, we next investigated the immunolocalization of CgAKR-1 in the C. gestroi gut for the first time (Fig. 2).

The interaction between anti-CgAKR-1 antibodies and target proteins in the gut of C. gestroi was investigated by immunolocalization. After incubation with both primary and secondary antibodies, the gut tissue showed strong fluorescence mainly located in the salivary gland, proventricle, and foregut (Fig. 2a). In contrast, there was nearly a completely lack of fluorescence in the hindgut (Fig. 2d). Strong fluorescence was also observed in the midgut (Fig. 2b) and the junction of the foregut and midgut. The foregut lumen of lower termites has high oxygen potential and harbors most digestive enzymes [2], such as C. gestroi endoglucanase (see Additional file 1: Figure S5). Thus, $C g A K R-1$ would be expected to be expressed in this gut section. In addition, CgAKR-1 was also detected in the malpighian tubules attached in the midgut (Fig. 2c). To the best of our knowledge, some PAD enzymes, such as cytochrome oxidase [36], a candidate enzyme involved in enzymatic detoxification and lignin degradation in termites [34, 37], are expressed in the malpighian tubules.

\section{CgAKR-1 was active against yeast fermentation inhibitor compounds}

Recombinant CgAKR-1 showed high affinity for the standard substrate 2-nitrobenzaldehyde (NBZ), with a $\mathrm{V}_{\max }$ of $2.34 \mathrm{U} / \mathrm{mg}$., $\mathrm{K}_{\mathrm{m}}$ of $0.15 \mathrm{mmol} / \mathrm{L}$, and $\mathrm{K}_{\text {cat }}$ of $7.5 \mathrm{~s}^{-1}$. In addition, the $K_{d}$ for cofactor NADPH was $0.06 \mathrm{mmol} / \mathrm{L}$. No activity was observed when NADH was used as a cofactor (data not shown). The specific activity of CgAKR-1 on NBZ was $1.53 \mu \mathrm{mol} / \mathrm{mg} / \mathrm{min}$ under optimal conditions at pH 5.7 (Fig. 3a) and $30{ }^{\circ} \mathrm{C}$ (Fig. 3b). This activity level was higher than that reported for $\mathrm{Sac}$ charomyces cerevisiae AKR $(0.34 \mu \mathrm{mol} / \mathrm{mg} / \mathrm{min})[38]$ and lower than that reported for human AKR1A1 under optimal conditions $(2.47 \mu \mathrm{mol} / \mathrm{mg} / \mathrm{min})$ [37].

The optimal $\mathrm{pH}$ of the enzyme was within the same range found in the gut of lower termites and was similar to the $\mathrm{pH}$ reported for rabbit AKR ( $\mathrm{pH}$ 5.6) [38]. Notably, however, aldehyde reductases from animals and fungi typically have an optimal $\mathrm{pH}$ at or near neutral $[28,31$, 39, 40]. Furthermore, CgAKR-1 was stable in the range of $20-35{ }^{\circ} \mathrm{C}$ and maintained residual activity (about $30 \%$ ) at temperatures from 50 to $80{ }^{\circ} \mathrm{C}$; no activity was observed at $90{ }^{\circ} \mathrm{C}$ (Fig. 3b).

Table 1 shows the specificity of CgAKR-1 for different substrates, as measured by the oxidation of NADPH. The high specificity of CgAKR-1 for 2-nitrobenzaldehyde has also been reported for various AKRs [39]. In general, the enzyme had high activity for aromatic and aliphatic aldehydes. No reductase activity was detected for vanillin, aldose sugars, propanone, and polysaccharides (data not shown). According to our data, $C g$ AKR-1 was active on several chemicals found in hemicellulosic hydrolysates from sugarcane bagasse (SCB), such as syringaldehyde, hydroxybenzaldehyde, HMF, and furfural, which can inhibit yeast fermentation [11]. The activity of an intestinal AKR on these aromatic aldehyde molecules could prevent electrophilic injury caused by these compounds and would be consistent with the fact that a similar AKR was induced by a lignin-rich diet in Reticulitermes flavipes $[7,28]$.

AKRs are able to generate $\mathrm{H}_{2} \mathrm{O}_{2}$ and other reactive oxygen species (ROS) via NADPH oxidation [41, 42]. We performed in vitro assays to quantify $\mathrm{H}_{2} \mathrm{O}_{2}$ production by $C g A K R-1$ because $\mathrm{H}_{2} \mathrm{O}_{2}$ can contribute to lignocellulose deconstruction [43-45]. Amplex Red assays revealed that $\mathrm{CgAKR}-1$ generated $0.55 \mathrm{mmol}$ of $\mathrm{H}_{2} \mathrm{O}_{2}$ per minute in the presence of $0.6 \mathrm{mmol} \mathrm{NADPH}$ (Fig. 4). The $\mathrm{H}_{2} \mathrm{O}_{2}$ generated from $\mathrm{CgAKR}-1$ was able to initiate the Fenton reaction in the presence of $\mathrm{Fe}^{2+}$, generating the ${ }^{\circ} \mathrm{OH}$ radi$\mathrm{cal}$, a powerful oxidant that can be utilized in lignocellulose degradation [45] (detected by a peroxynitrite sensor [HPF]; see Additional file 1: Figure S7). 


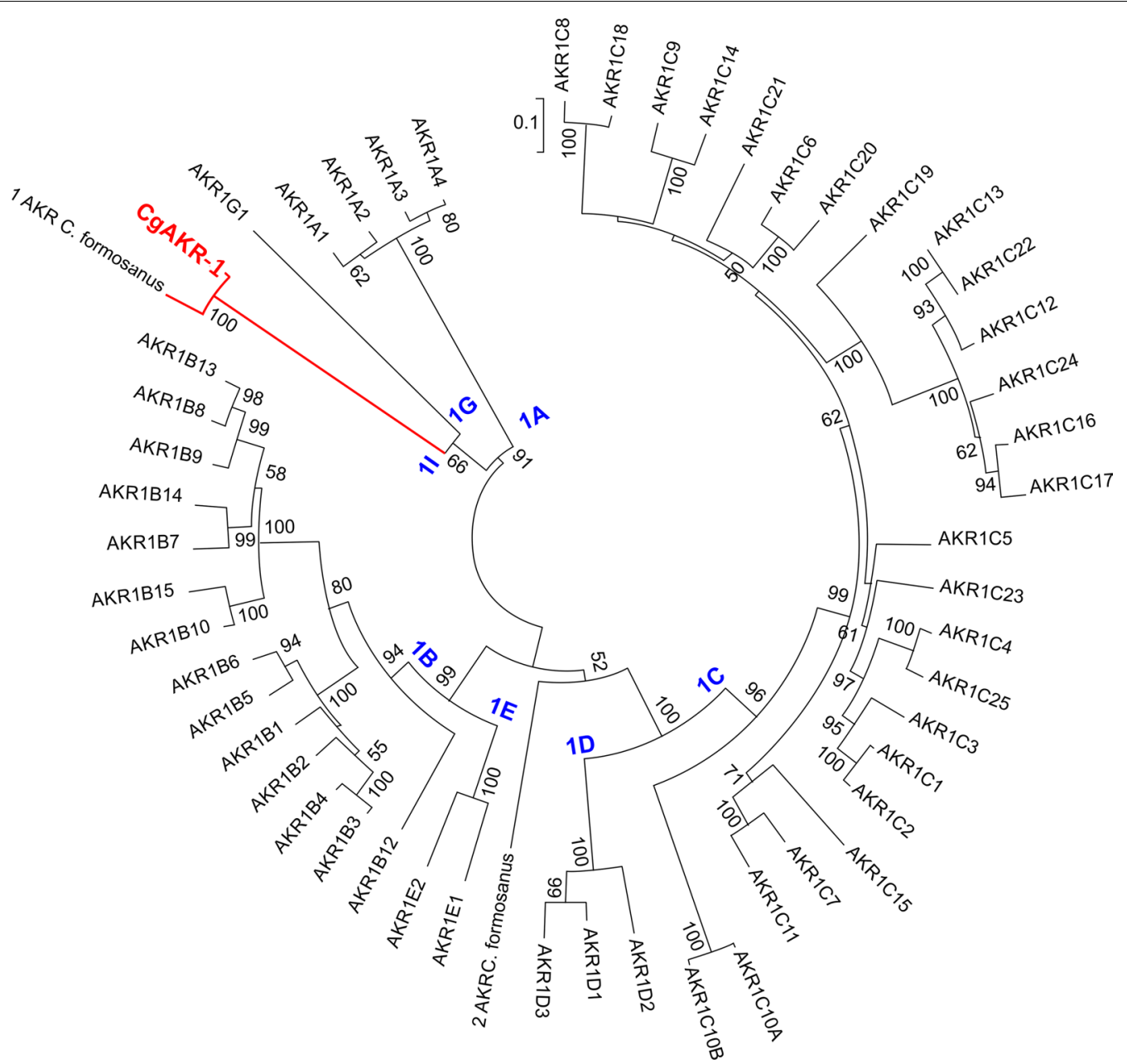

Fig. 1 Phylogenetic tree of members of the AKR superfamily. Amino acid sequences (AKR1 family) were found in the AKR database (https://www. med.upenn.edu/akr/), and CgAKR-1 and a related termite AKR sequence (AGM32584.1) were added. The dendrogram was generated as described by Hyndman [38]. The tree was constructed with the neighbor-joining method implemented in MEGA6.0 using 1000 bootstraps. The evolutionary distances were computed using the JTT matrix-based method and are presented as the number of amino acid substitutions per site. Evolutionary analyses were conducted in MEGA6

Thus, we concluded that in addition to its ability to reduce aldehydes, $C g A K R-1$ had an NADPH oxidase-like function and could generate ROS, such as $\mathrm{H}_{2} \mathrm{O}_{2}$, during in vitro assays. In the presence of reducing agents, such as $\mathrm{Fe}^{2+}$ (present in termite guts), the hydroxyl radical could also be produced through the action of $C g$ AKR-1.

\section{Loop B of CgAKR-1 was longer than that of other AKRs}

The three-dimensional structure of $C g A K R-1$ revealed a conserved structure, known as the $(\beta / \alpha)_{8}$ barrel, within the AKR superfamily [46]. This structure consisted of eight $\beta$-strands in the central region surrounded by eight $\alpha$-helices (see Additional file 1: Figure S6). The NADPbinding site is buried in the protein structure and is highly conserved throughout members of the AKR superfamily, despite the low similarity of other regions of the protein [47]. AKRs from family 1 generally show specificity for NADPH, corroborating our results [28]. CgAKR-1 displays structural determinants that underlie the preference for NADPH, which is related to the positively charged arginine residues that bind to pyrophosphate backbone and the $5^{\prime}$ phosphate group of NADPH (Fig. 5) [48]. The amino acids W24, N47, Y52, H114, S166, N167, Y214, I217, S219, K276, S277, R282, E285, and N286 surrounded the cofactor (Fig. 5a). In addition, the catalytic residues were identified as D47, Y52, K81, and H114 and were also conserved. In general, the amino acid composition of the substrate-binding sites in AKRs is diverse and confers different substrate specificities to each AKR subfamily [30]. The inner region of the substrate-binding site was found by the $C$-terminal region of the $\beta$-strands together with the NADP nicotinamide group, and the 


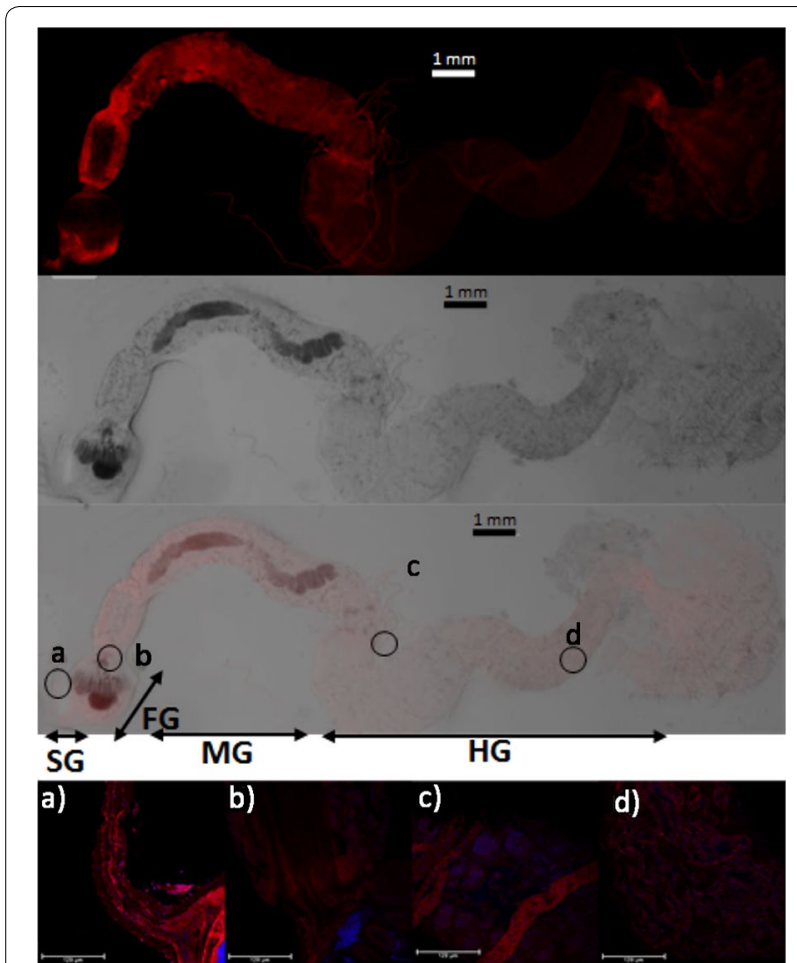

Fig. 2 Immunolocalization of CgAKR-1 in C. gestroi gut tissues. Gut tissues were incubated with primary anti-CgAKR-1 antibodies and AlexaFluor 568 secondary antibodies and observed under a Leica DMI 6000 microscope. Red fluorescence indicates anti-CgAKR-1 antibody binding; gray represents the gut visualization under white light; and blue fluorescence represents the nucleus in all cells using ProLong Antifade Reagent for Fixed Cells. Images from the red, blue, and white channels were recorded independently and digitally overlaid to produce a final image. Whole gut: salivary glands (SG); foregut (FG); midgut (MG); hindgut ( $\mathrm{HG}$ ). The letters indicate multiple layer image analysis: a) foregut, $b$ ) midgut, c) malphigian tubes $d$ ) hindgut. The scale bar corresponds to $124 \mu \mathrm{m}$ length. Further details of immunolocalization of CgAKR-1 are presented in the Additional file 1 binding site entrance was composed by loops connecting $\beta$-strands with $\alpha$-helices (Fig. 5b).

The superposition of CgAKR-1 chain A with AKRs complexed with substrates indicated that the substratebinding site was delimited by the amino acids W24, M51, Y52, H114, L115, W128, R229, F314, and M316 (Fig. 5c).

One major feature of the CgAKR-1 structure was the presence of a longer loop (known as loop B) between the seventh and eighth $\beta$-strands of the barrel (residues L222 to L242) compared with that of other AKRs (Fig. 5b, d). This longer loop also exhibited high mobility based on high B-factor in chain A, which could not be modeled in chain $B$ owing to the absence of a defined electron density. According to Barski et al. [30], loop B is part of a "hot spot" for variability between the AKR families and is responsible for multiplicity of substrate specificity and kinetic properties. In addition, loop B from AKR1A and AKR1B has an open-and-close movement for cofactor entrapment [49]. Consequently, the unparalleled long loop B from CgAKR-1 seemed to play an important role, not only in cofactor binding but also in substrate interaction owing to the arginine (R229) positioned towards the substrate-binding site (Fig. 5).

\section{CgAKR-1 exhibited efficient hemicellulosic hydrolysate detoxification and improved yeast conversion of xylose to ethanol}

CgAKR-1 was added to the hemicellulosic hydrolysate prior to fermentation in order to validate the detoxification capacity of the enzyme. After the enzymatic detoxification step, $32 \%$ of furfural and $15 \%$ of soluble lignin were eliminated (Fig. 6a). Fermentation of the detoxified hemicellulosic hydrolysate by Scheffersomyces stipitis at over $72 \mathrm{~h}$ was also evaluated (Table 2). There was a $45 \%$ increase in ethanol production compared with that of the
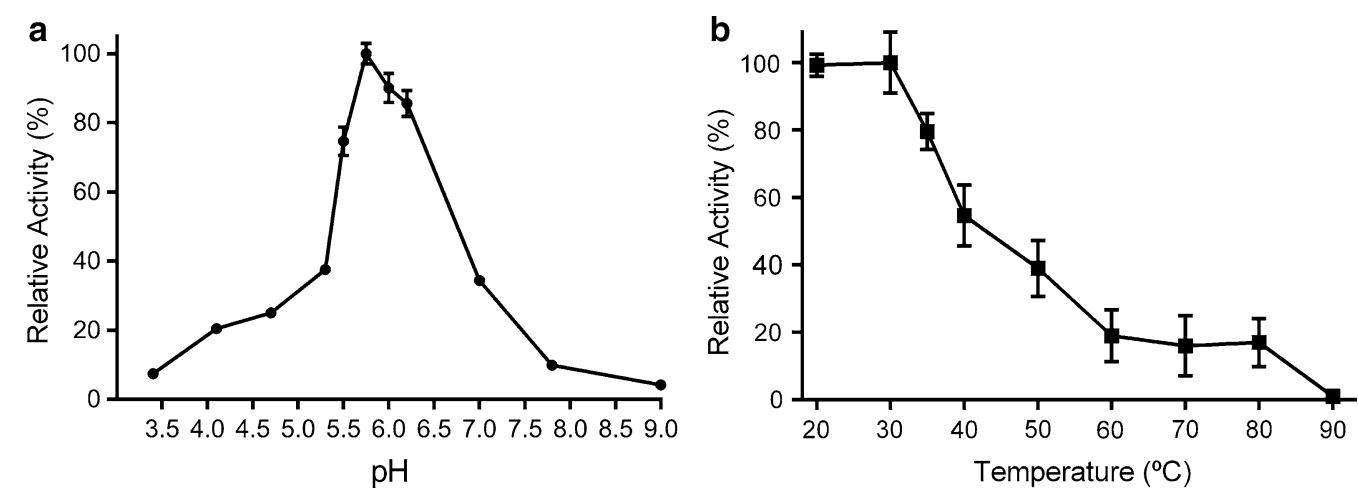

Fig. 3 Biochemical properties of CgAKR-1. a Effects of pH on CgAKR-1 activity. Phosphate buffer (pH 3.0-8.0) and Tris buffer (pH 8.5-9.0) were used at $100 \mathrm{mM}$ at $30^{\circ} \mathrm{C}$. The results were expressed as relative activity (\%) in relation to optimal pH of 5.7. $\mathbf{b}$ CgAKR-1 thermostability. The enzyme was incubated at pH 5.7 for 30 min at different temperatures. After incubation, the standard enzyme assay was performed, and the results were expressed as relative activity (\%) in relation to the optimal temperature of $30^{\circ} \mathrm{C}$ 
Table 1 CgAKR-1 substrate specificity

\begin{tabular}{lll}
\hline Substrate (2 mmol/L) & Relative activity (\%) Structure \\
\hline 2-Nitrobenzaldehyde & 100 \\
5-Hydroxymethylfurfural & 116 \\
4-Hydroxybenzaldehyde & 61 \\
Syringaldehyde & 112 \\
Acetaldehyde & 72 \\
\hline
\end{tabular}

Specific activity was determined as $\mu$ mol of NADPH oxidized per min per $\mathrm{mg}$ protein. Relative activities of $C g A K R-1$ using different substrates are presented as the percentage of CgAKR-1 activity on 2-nitrobenzaldehyde

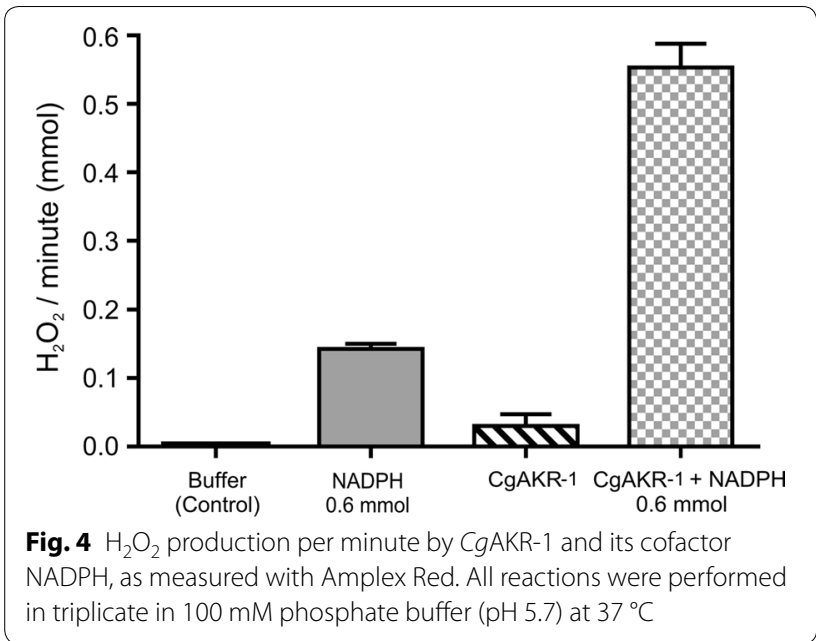

control (control: 5.59 g/L; CgAKR-1: 8.84 g/L; Fig. 6b). The concentration of cells after fermentation was not significantly altered (control: $19.5 \pm 1.3 \mathrm{~g} / \mathrm{L} ; \mathrm{CgAKR}-1$ : $18.4 \pm 1.5 \mathrm{~g} / \mathrm{L})$.

According to Wahlbom [50], fermentation inhibitors can cause the depletion of redox cofactors during fermentation, resulting in slower, decreased ethanol production by yeast. The inhibitory effects can vary according to the chemical functional groups, and aldehydes are more harmful than other functional groups [11]. The diversity of inhibitory aldehyde structures reduced by $C g A K R-1$ indicated that this enzyme was able to enhance alcoholic fermentation of this type of biomass by the detoxification of both furfural and phenolic and aldehyde derivatives from lignin (Table 1).

The detoxification of hemicellulosic hydrolysates is of biotechnological interest, and many detoxification methods have been reported in the literature $[9,11,14,17$, $32,51]$. Laccases and peroxidases are being applied in the development of enzymatic cocktails for detoxification of lignin components, consuming or generating ROS such as $\mathrm{H}_{2} \mathrm{O}_{2}$ to remove soluble lignin in fermentation medium; thus, PAD enzymes such as CgAKR-1 could also be applied for this purpose $[10,52,53]$. The degradation of lignin and cellulose, which are covalently linked in the biomass (through hemicelluloses), could be performed by oxidative steps [54]. Thus, we suggested that the hydrogen peroxide produced by $C g \mathrm{AKR}-1$ could oxidize the soluble lignin as well [55].

\section{CgAKR-1 improved lignocellulose hydrolysis by $\mathrm{H}_{2} \mathrm{O}_{2}$ production}

Next, we performed assays combining CgAKR-1, CgGH9 (C. gestroi endoglucanase [56]), and CAT (a commercial catalase that catalyzes the decomposition of $\mathrm{H}_{2} \mathrm{O}_{2}$ to water and oxygen) in order to evaluate whether the synergism of these enzymes on barley beta-glucan saccharification could be correlated with ROS generation. Hydrolysis with $\mathrm{CgGH} 9$ released reducing sugars and background $\mathrm{H}_{2} \mathrm{O}_{2}$ production (Fig. 7). The addition of CgAKR-1 to CgGH9 improved the hydrolysis of betaglucan, with a degree of synergism (DS) of 1.68, generating $17 \mathrm{mmol}$ of $\mathrm{H}_{2} \mathrm{O}_{2}$ after a 1-h reaction. The maximum cooperation between the enzymes was found after $14 \mathrm{~h}$ of hydrolysis (DS: 2.04). However, the addition of a CAT enzyme to this reaction abolished the synergism and concomitantly led to lower production of $\mathrm{H}_{2} \mathrm{O}_{2}$ (Fig. 7a).

There were synergistic enzymatic interactions between CgAKR-1 and C. gestroi endoglucanase. Our data indicated that the additive enzymatic activity could be mediated by ROS because improvement of glucan polysaccharide hydrolysis was correlated with $\mathrm{H}_{2} \mathrm{O}_{2}$ production (Fig. 7a). Glucan oxidation occurs via $\mathrm{H}_{2} \mathrm{O}_{2}$ through generation of new carbonyl and carboxyl groups in the polysaccharide, which could cleave the glucosidic bonds of cellulose [42, 43]. Several enzymes have been reported to improve lignocellulose hydrolysis in the presence of $\mathrm{H}_{2} \mathrm{O}_{2}$ and other oxygen species [45, 57-60].

Moreover, to further explore the potential biotechnological applications of this enzyme, we performed 

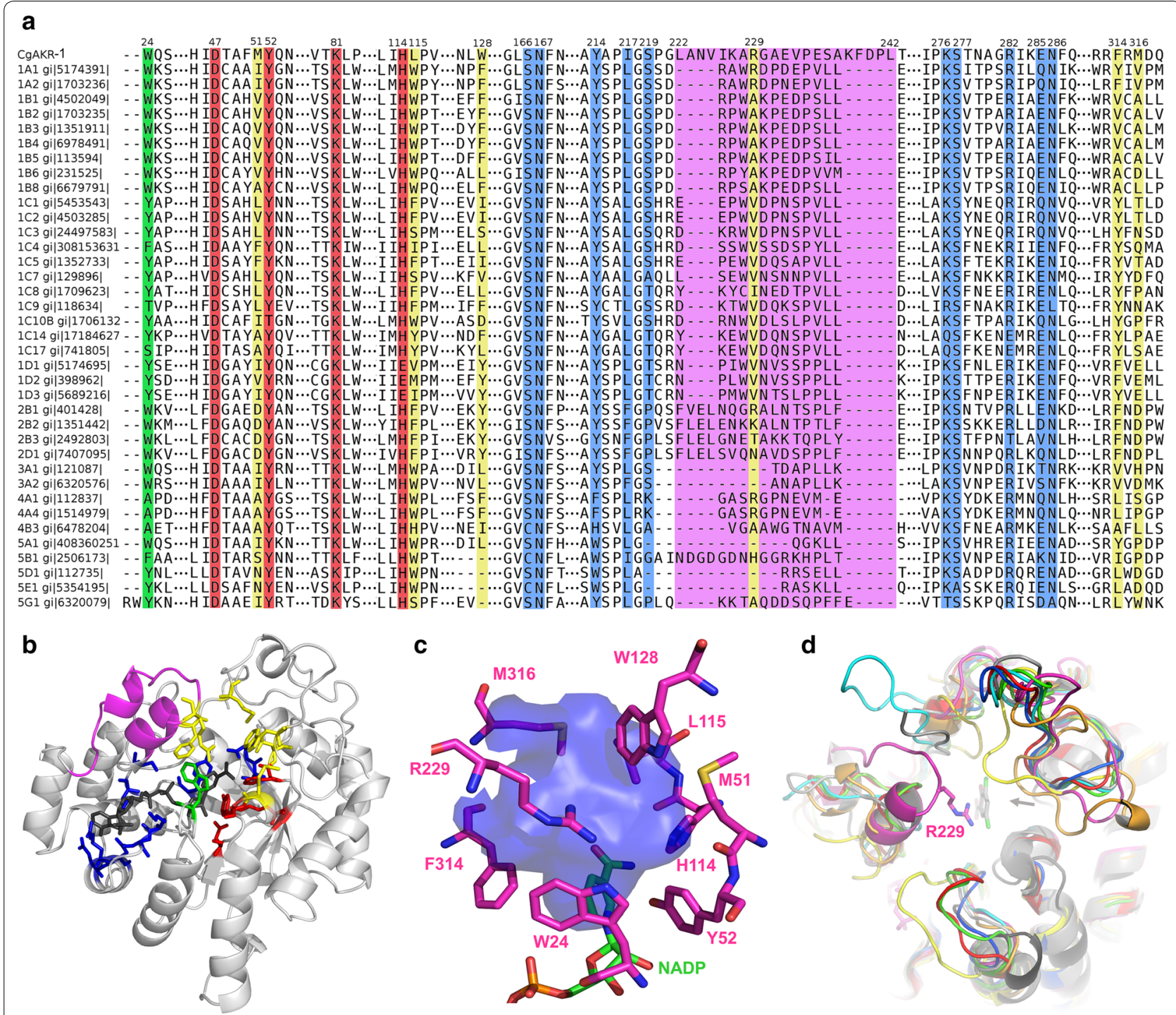

Fig. 5 Sequence comparison and structural assignment. a Multiple sequence alignment of CgAKR with members of the most similar related families AKR1-5. Despite the low identity among CgAKR-1 and other AKR enzymes, the catalytic residues (red) and the residues that interacted with the cofactor (blue) had a high degree of similarity. The residues that surrounded the substrate (yellow) were more diverse between each family, reflecting the specificity for different substrates. The position that interacted with both the substrate and cofactor is shown in green. One of the main differences between CgAKR-1 and the other enzymes was the presence of a longer loop, known as loop B (magenta), located in the substrate-binding site. b Positioning of the important amino acids in the CgAKR-1 crystallographic structure (the colors in $\mathbf{b}$ are the same as those in a). c Substratebinding site. The cavity in the CgAKR-1 structure, represented here as a blue surface, was determined to be the substrate-binding site by comparison with other substrate-complexed AKRs. Therefore, the pocket was mainly delimited by the cofactor (NADP) and nine amino acids with different properties, including R229 from loop B (observed only in CgAKR-1). d Superposition of CgAKR-1 with other AKRs from different families: 1A1 complexed with 3,5-dichlorosalicylic acid (gray arrow) in gray (PDBid 3cv7), 1B in blue (PDBid 4hbk), 1C in green (PDBid 1ihi), 1D in red (PDBid 3buv), 2B in orange (PDBid 1mi3), 4A in yellow (PDBid 1zgd), and 5C in black (PDBid 1hw6). The loops comprised the entrance to the substrate-binding site. Despite the discernible variations in size and position, CgAKR-1 (magenta) had one loop (loop B, indicated with a magenta arrow) that was longer than the others. This loop also contained an arginine (R229) that may interact with the substrate

Celluclast 1.5 L supplementation with CgAKR-1, which resulted in significant improvements in saccharification yield (Fig. 7b). The highest DS values were found for the hydrolysis of phosphoric acid-pretreated sugarcane bagasse (PASB; 1.48 at $2 \mathrm{~h}, 2.17$ at $6 \mathrm{~h}$, and 1.31 at $24 \mathrm{~h}$; Fig. 7b). In contrast, CgAKR-1 synergistically enhanced the hydrolysis of raw sugarcane bagasse (SCB) at early time points (DS of 1.46 at $2 \mathrm{~h}$ ), with reduced effects at 


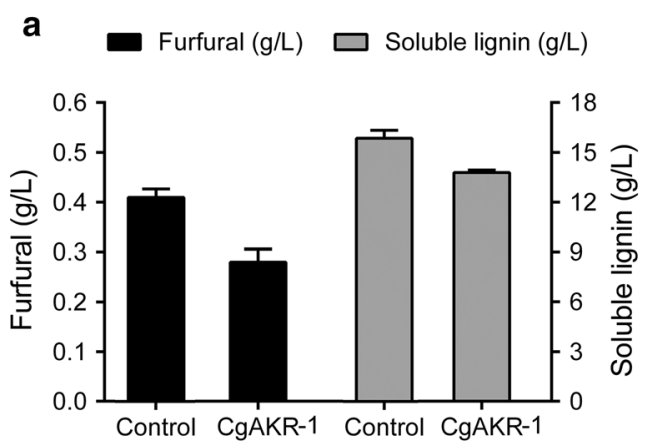

$$
\text { b } \quad \rightarrow \text { Control (Xylose) } \rightarrow \text { - CgAKR-1(Xylose) }
$$

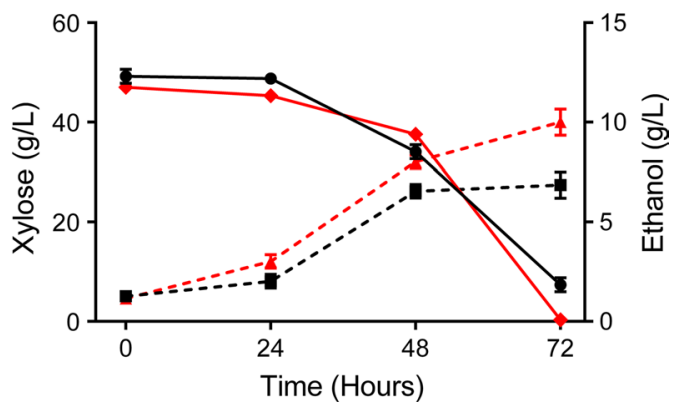

Fig. 6 Effects of CgAKR-1 on hemicellulosic hydrolysate detoxification followed by alcoholic fermentation using S. stipitis. The fermentation was carried out at $30^{\circ} \mathrm{C}$ and $200 \mathrm{rpm}$ for $72 \mathrm{~h}$. Analysis was carried out by HPLC with three biological replicates. a Amounts of furfural and soluble lignin after detoxification; $\mathbf{b}$ ethanol production by S. stipitis and xylose consumption by S. stipitis

Table 2 S. stipitis fermentation parameters after hemicellulosic hydrolysate detoxification by CgAKR-1

\begin{tabular}{lcc}
\hline Parameters & Control experiment & $\begin{array}{l}\text { Detoxification } \\
\text { by CgAKR-1 }\end{array}$ \\
\hline$Y p / s(g / g)$ & 0.13 & 0.19 \\
$Y(\%)$ & 26.19 & 37.12 \\
Xylose consumption (\%) & 85.00 & 99.28 \\
\hline
\end{tabular}

$Y p / s$ xylose conversion factor in ethanol, $Y$ percentage of ethanol production

later time points (DS of 1.13 at $24 \mathrm{~h}$ ). In both cases, $\mathrm{H}_{2} \mathrm{O}_{2}$ generation was found to correlate with improved saccharification (Fig. 7b).

The major difference in composition between SCB and PASB is regarding the content of hemicelluloses and lignin (PASB composition, as a percentage of dry mass: $59.0 \%$ cellulose, $1.8 \%$ hemicellulose, and $30.0 \%$ lignin [61]; SCB composition as a percentage of dry mass: $42.8 \%$ cellulose, $25.8 \%$ hemicellulose, and $22.1 \%$ lignin [62]). Lignin is responsible for blocking cellulolytic enzymes acting in bagasse fibers by nonproductive binding [11]. Hence, improvement of commercial cocktail performance is related to the generation of $\mathrm{H}_{2} \mathrm{O}_{2}$ by $\mathrm{Cg}$ AKR1 , which could result in lignin degradation through the cleavage of lignin-carbohydrate linkages, such as $\beta-1,4$ aryl ether linkages, and loss of cellulose crystallinity [63].

Collectively, our data suggested that oxidative cleavage mechanisms could significantly improve the yields of plant biomass deconstruction to biomass, demonstrating potential bioproduct applications [64]. Classical cellulase mixtures (e.g., Celluclast) do not generate reasonable yields of $\mathrm{H}_{2} \mathrm{O}_{2}$ or $\mathrm{OH}$ radical during reaction with biomass (see Additional file 1: Figure S8). These redox agents, which are active against lignocellulose, can be generated by PAD enzymes, which are therefore good candidates for the formulation of next-generation lignocellulosic cocktails (see Additional file 1).

According to the data presented in this study, CgAKR-1 improved lignocellulose saccharification and yeast fermentation via two different proposed mechanisms: 1 ) the reduction of fermentation inhibitory compounds found in lignocellulose, and 2) the promotion of synergistic enzymatic interactions with glycoside hydrolases. However, there were some limitations to this study. First, the saccharification process at $50{ }^{\circ} \mathrm{C}$ is limited by the low thermal stability of $C g A K R-1$. Additionally, we used a host that would not be suitable for industrial expression. Thus, improvement of thermostability through protein engineering and protein production by filamentous fungi could facilitate the industrial application of this method using endogenous enzymes from termites as a potential tool for biomass conversion. Therefore, studies involving CgAKR-1 have greatly improved our understanding of termite biology and the role of this protein in both saccharification and fermentation steps as a "multipurpose enzyme," functioning to mediate process integration during second-generation ethanol production and for green chemistry purposes.

\section{Conclusion}

This work describes a founding member of AKR superfamily 1I, providing a basis for the involvement of endogenous enzymes, as components of the C. gestroi digestome, in redox mechanisms. Biotechnologically, CgAKR-1 was found to be a versatile enzyme that was capable of detoxifying hemicellulosic hydrolysates for pentose fermentation and enhancing SCB saccharification via glycoside hydrolases. $C g A K R-1$ provided a basis for the development and application of integrative and multipurpose enzymes as components in the bioethanol and biochemical production chain. 


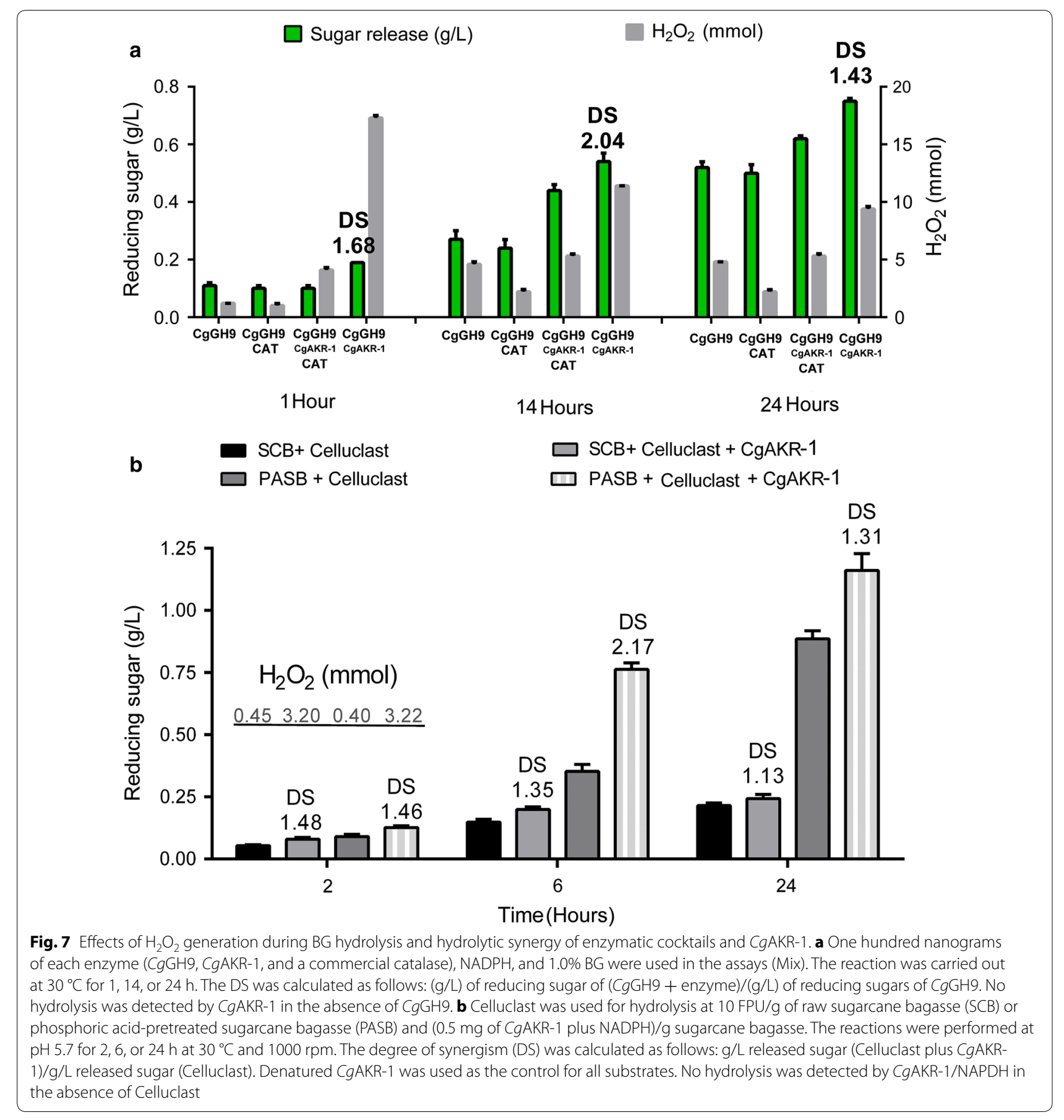

\section{Methods}

\section{Collection and treatment of $C$. gestroi}

For gene amplification and gut isolation, specimens of $C$. gestroi were maintained in the Termite Laboratory of the Biology Department, UNESP, Rio Claro, São Paulo, Brazil $\left(22^{\circ} 23^{\prime} \mathrm{S}, 47^{\circ} 31^{\prime} \mathrm{W}\right)$ after collecting them from field colonies with traps of corrugated cardboard. Termites were kept at $25 \pm 2{ }^{\circ} \mathrm{C}$ and fed on pinewood with $10 \%$ humidity until use.

\section{Phylogenetic tree of the AKR superfamily}

The amino acid sequence (GenBank accession number: KU686221) of C. gestroi [26] was evaluated by comparison with multiple sequence analysis in the PFAM database, indicating the presence of a conserved domain from the AKR superfamily. To elucidate the function of this AKR, the amino acid sequence identified as CgAKR-1 was submitted to phylogenetic analysis [35]. The phylogenetic tree was generated as described previously, 
including specifications according to the AKR superfamily homepage [35]. Briefly, the superfamily tree was constructed with the neighbor-joining method using 1000 bootstraps [65]. The tree was drawn to scale, with branch lengths in the same units as those of the evolutionary distances used to infer the phylogenetic tree. The evolutionary distances were computed using the JTT matrix-based method [66] and are presented as the number of amino acid substitutions per site. Previous analyses including all AKR family members were performed, confirming the classification of CgAKR-1 in the AKR-1 family [35], as presented in Additional file 1: Figure S1. Subsequently, a refined analysis of 53 amino acid sequences, including known AKRs from family 1, such as CgAKR-1 and related and well-described AKRs, was performed. All positions with less than $95 \%$ site coverage were eliminated. There were a total of 307 positions in the final dataset. All the analyses were conducted in MEGA6 [67].

\section{Cloning and expression of $C$. gestroi AKR}

The sequence encoding full-length CGAKR1 was amplified from C. gestroi cDNA using a standard polymerase chain reaction (PCR) method, as previously described [56]. Two nucleotide primers were used, as follows: (forward, 5'-TAAAATGCTAGCATGCCTAAACAACTGAGCAGT-3', and reverse, 5'-TATTATGGATCCCTAATAAGGCTCATCATACGGGT-3'; restriction enzyme recognition sites are underlined). The PCR product was recovered after $1 \%$ agarose electrophoresis and further digested with NheI and BamHI enzymes according to the manufacturer's instructions. Finally, the double-digested PCR product was ligated into the pET-28(a) vector (Novagen) after treatment with the same two enzymes, allowing for insertion of a $6 \mathrm{X}-\mathrm{His}$ tag sequence at the $\mathrm{N}$-terminal position [56]. After cloning and sequencing, gene characterization was performed using Protparam, SignalP, and SecretomeP platforms. The E. coli strain ArcticExpress (DE3-T7 promoter; Agilent Technologies) competent cells were transformed with the pET-28a (Novagen)/CGAKR1 plasmid and plated in selective solid LB medium containing kanamycin $(50 \mathrm{mg} / \mathrm{L})$. Cells from a single colony were grown in liquid LB containing kanamycin $50 \mathrm{mg} / \mathrm{L}$ for $16 \mathrm{~h}$ at $37^{\circ} \mathrm{C}$ and $200 \mathrm{rpm}$. The cultures were then diluted in $600 \mathrm{~mL}$ fresh LB medium containing kanamycin and grown at $30{ }^{\circ} \mathrm{C}$ and $200 \mathrm{rpm}$ for $4 \mathrm{~h}$. The temperature and rotation were then reduced to $12{ }^{\circ} \mathrm{C}$ and $120 \mathrm{rpm}$, respectively. After $1 \mathrm{~h}$ of acclimation, expression of the recombinant protein was induced by the addition of $1 \mathrm{mM} / \mathrm{L}$ isopropyl $\beta$-D-1-thiogalactopyranoside. After $24 \mathrm{~h}$, the cells were harvested by centrifugation at $8500 \times g$. The cells were resuspended in lysis buffer $(20 \mathrm{mM}$ sodium phosphate [pH 7.5], $500 \mathrm{mM} / \mathrm{L} \mathrm{NaCl}, 5 \mathrm{mM}$ imidazole, $80 \mathrm{~g} / \mathrm{L}$ egg lysozyme, and $5 \mathrm{mM}$ polymethylsulfonyl fluoride [PMSF]) and then disrupted in an ice bath using an ultrasonic processor (seven pulses of $10 \mathrm{~s}$ at $500 \mathrm{~W}$; VC750 Ultrasonic Processor, Sonics Vibracell). After that, the AKR from the supernatant was purified by chromatography using an AKTA FPLC system (GE Healthcare, Waukesha, WI, USA) using a 5-mL HiTrap Chelating HP column (GE Healthcare) charged with $\mathrm{Ni}^{2+}$ followed by a Superdex 200 10/300 GL column (GE Healthcare), as previously described [68]. The concentration of purified AKR was measured using a NanoDrop 2000c instrument (Thermo Scientific, USA) and calculated using the molar extinction coefficient $\left(37,025^{1} \mathrm{~cm}^{-1}\right)$.

\section{Crystallization, X-ray diffraction, and structure determination}

The purified protein was concentrated to $10 \mathrm{mg} / \mathrm{mL}$ prior to crystallization assays. Initial crystallization experiments were set up using the sitting drop vapor diffusion method on a Honey Bee 963 robot at the ROBOLAB facility (LNBio-CNPEM) in a 96-well plate with drops composed of $0.5 \mu \mathrm{L}$ protein solution plus $0.5 \mu \mathrm{L}$ reservoir solution. Commercial kits from Hampton were used as initial conditions. A second round of crystallization was performed to refine the hits obtained in first experiment using the hanging drop vapor diffusion technique with the drops composed of $2 \mu \mathrm{L}$ of protein solution and $2 \mu \mathrm{L}$ of reservoir solution. All crystals were grown at $18{ }^{\circ} \mathrm{C}$. The X-ray diffraction data were collected at $100 \mathrm{~K}$ using a beamline MX-2 with a Brazilian Synchrotron Light Source-LNLS (Campinas, Brazil), equipped with a Pilatus $6 \mathrm{M}$ detector. Once the crystals were dissolved in the presence a cryoprotectant, they were directly transferred from the drops to the goniometer. The spots located in the ice ring areas were excluded for data indexing and integration. The collected data were indexed and integrated with XDS [69] and scaled with Aimless [70]. The initial phases were calculated by molecular replacement with Phaser [71] using the structure of aldose reductase from Schistosoma japonicum (PDBid 4hbk) as a search model. The structure adjustment and analysis were made with COOT [72], and refinement was performed with Phenix [73]. The final structure factors and model were validated with Molprobity [74] and deposited in the PDB databank with accession code 5KET. For more crystallization and data processing details, please see the Additional file 1: Table S1 and Figure S6.

\section{CgAKR-1 immunolocalization in C. gestroi gut tissue}

The immunolocalization of CgAKR-1 was analyzed in the termite gut according to methods described by Price et al. [75]. The purified protein CgAKR-1 was used to produce polyclonal antibodies in rabbits (commissioned 
with RHEABIOTECH Ltd.), according to standard protocols (www.rheabiotech.com.br). IgG fractions were purified from rabbit serum by protein $G$ affinity chromatography (Amersham), according to the manufacturer's instructions. Eluted antibodies were concentrated to $10 \mathrm{mg} / \mathrm{mL}$.

For analysis of protein immunolocalization, termites were washed in $70 \%(\mathrm{v} / \mathrm{v})$ ethanol, followed by phosphate-buffered saline (PBS), and the complete guts were then dissected out in PBS with PMSF (0.2 mM), ethylenediaminetetraacetic acid (EDTA; $1 \mathrm{mM}$ ), and leupeptin $(20 \mu \mathrm{M})$. After dissection, guts were transferred to a tube containing $2 \%(\mathrm{w} / \mathrm{v})$ paraformaldehyde. The gut tissue was then fixed for $2 \mathrm{~h}$ at room temperature. After fixation, gut tissues were washed several times in $1 \times$ PBS. Nonspecific antibody binding was prevented by incubating the gut tissue for $1 \mathrm{~h}$ in a solution containing $4 \%$ (v/v) Triton X-100 with $2 \%(\mathrm{w} / \mathrm{v})$ bovine serum albumin (BSA) in PBS. After blocking, the tissue was incubated in primary antibody with shaking at $4{ }^{\circ} \mathrm{C}$ for $24 \mathrm{~h}$. AntiCgAKR-1 antibodies were used at a concentration of 1:1000 in antiserum buffer $(0.4 \%[\mathrm{v} / \mathrm{v}]$ Triton X-100 with $2 \%[\mathrm{w} / \mathrm{v}] \mathrm{BSA}$ in PBS). Gut tissues were then washed in PBS at $4{ }^{\circ} \mathrm{C}$ for $24 \mathrm{~h}$. AlexaFluor 568 (red) secondary antibodies were incubated with the tissue specimens at a concentration of $1: 200$ in antiserum buffer at $4{ }^{\circ} \mathrm{C}$ for $18 \mathrm{~h}$. The secondary antibody solution was removed, and the tissues were washed in PBS at $4{ }^{\circ} \mathrm{C}$ for $18 \mathrm{~h}$. Immunostained gut samples were mounted on glass slides. Control experiments were run in parallel and consisted of a primary antibody-only control and a secondary antibody-only control. Control experiments were set up following the same procedure, except the appropriate antibody incubation stage was omitted (see Additional file 1: Figure S4). Additionally, the immunolocalization of termite endoglucanase $(\mathrm{CgGH} 9)$ was analyzed as a positive control (see Additional file 1: Figure S5). Additional information about equipment and settings can be found in Additional file 1.

\section{Enzymatic assay}

AKR activity was assayed spectrophotometrically at $30^{\circ} \mathrm{C}$ by monitoring the decrease in the absorbance of NADPH at $340 \mathrm{~nm}$ in microplates. The standard assay mixture $(0.2 \mathrm{~mL})$ was composed of $50 \mathrm{mM}$ sodium phosphate buffer ( $\mathrm{pH}$ 7.0), $5.0 \mathrm{mmol} / \mathrm{L}$ substrate (2-nitrobenzaldehyde, furfural, HMF, etc.), and $2.5 \mu \mathrm{g} C g \mathrm{AKR}-1$. Additionally, $0.2 \mathrm{mmol} / \mathrm{L} \mathrm{NADPH}$ was added to the plate to initiate the reaction, and the reaction rate was measured against an identical blank with no enzyme added. Activity was measured for $5 \mathrm{~min}$. One unit of enzyme activity was defined as the amount of enzyme catalyzing the oxidation of $1 \mu \mathrm{mol} \mathrm{NADPH}$ per minute $(\mu \mathrm{mol} / \mathrm{mg} / \mathrm{min})$ under the described assay conditions. The kinetic parameters of the purified enzyme were determined by assaying activities at different NADPH concentrations using $5 \mathrm{mM}$ 2-nitrobenzaldehyde as the substrate. Furthermore, activities at different 2-nitrobenzaldehyde concentrations were measured using $0.2 \mathrm{mM}$ NADPH. Optimal $\mathrm{pH}$ was determined using phosphate buffer ( $\mathrm{pH}$ 3.0-8.0) and Tris buffer ( $\mathrm{pH} 8.5-9.0)$ at $100 \mathrm{mM}$ at $30^{\circ} \mathrm{C}$. Thermo residual stability was measured after enzyme incubation for $30 \mathrm{~min}$ at different temperatures at a fixed $\mathrm{pH}$ of 5.7. The results were expressed in relative activity (\%).

\section{Detection of ROS}

$\mathrm{H}_{2} \mathrm{O}_{2}$ generation was measured using Amplex Red, as previously described [76], with a Catalase Assay Kit (cat. no. A22180; Life Technologies) at $571 \mathrm{~nm}$. Fifty microliters of the sample was used in the assay. A hydroxyphenyl fluorescein (HPF) assay kit was used for $\mathrm{OH}$ detection (see Additional file 1), and samples were incubated with $40 \mu \mathrm{L}$ of $50 \mu \mathrm{M}$ HPF [77]. Denatured CgAKR-1 was used as a negative control, and one reaction with $5 \mathrm{mM} \mathrm{FeSO}_{4}$ was performed to evaluate the Fenton chemistry if $\mathrm{H}_{2} \mathrm{O}_{2}$ was being generated by $C g A K R-1$. The reactions were kinetically monitored over $30 \mathrm{~min}$ at $35^{\circ} \mathrm{C}$ using a plate reader fluorometer (Molecular Devices). The excitation wavelength was $488 \mathrm{~nm}$, and the emission wavelength was $515 \mathrm{~nm}$. All reactions were performed in triplicate.

\section{Detoxification of hemicellulosic hydrolysate by CgAKR-1}

The detoxification step was performed by CgAKR-1 application in the liquid fraction (hemicellulosic hydrolysate) obtained after pretreatment. This fraction consisted of monomeric sugars, organic acids, furanic aldehydes, and phenolic compounds, with the following chemical composition: arabinose $(21.59 \mathrm{~g} / \mathrm{L})$, glucose $(31.90 \mathrm{~g} / \mathrm{L})$, xylose $(209.21 \mathrm{~g} / \mathrm{L})$, cellobiose $(5.08 \mathrm{~g} / \mathrm{L})$, formic acid $(0.66 \mathrm{~g} / \mathrm{L})$, acetic acid $(6.45 \mathrm{~g} / \mathrm{L})$, HMF $(0.12 \mathrm{~g} / \mathrm{L})$, furfural $(0.85 \mathrm{~g} / \mathrm{L})$, levulinic acid $(1.12 \mathrm{~g} / \mathrm{L})$, and soluble lignin $(25.32 \mathrm{~g} / \mathrm{L})$, as reported by Santoro et al. [78]. To evaluate whether CgAKR-1 could be applied to enzymatic in situ detoxification of fermentation inhibitors in hemicellulosic hydrolysate, samples were sterilized at $111^{\circ} \mathrm{C}$ for $5 \mathrm{~min}$ and diluted twice with $100 \mathrm{mM}$ potassium phosphate buffer ( $\mathrm{pH} 5.0$, adjusted with $6 \mathrm{M} \mathrm{NaOH}$, which was added slowly to ensure that the lignin would not precipitate). Subsequently, $1 \mathrm{mg}$ CgAKR-1 and NADPH $(2 \mu \mathrm{M})$ were added to the reaction and incubated at $30^{\circ} \mathrm{C}$ for $16 \mathrm{~h}$. After incubation, hemicellulosic hydrolysate alcoholic fermentation was performed. The yeast used in this study was the wild-type S. stipitis NRRL Y7124 strain, a xylose-fermenting microorganism capable to ferment the hemicellulosic hydrolysate [79, 80]. During this process, $3 \mathrm{~g} / \mathrm{L}$ yeast extract was added to the liquor, 
and S. stipitis yeast was inoculated at a final concentration of $10 \mathrm{~g} / \mathrm{L}$ in $50 \mathrm{~mL}$; the hemicellulosic hydrolysate was present at a final dilution of $4 \times(+$-xylose, $50 \mathrm{~g} / \mathrm{L})$. Thereafter, the experiment was incubated at $30{ }^{\circ} \mathrm{C}$ with continuous agitation at $200 \mathrm{rpm}$ for $72 \mathrm{~h}$, as described by Dussán et al. [81], using shake flasks. Glucose, xylose, acetic acid, glycerol, xylitol, furfural, and ethanol were measured during the fermentation according to the analytical measurements described below. Yeast concentrations $(\mathrm{g} / \mathrm{L})$ and kinetic parameter calculations $(\mathrm{Yp} / \mathrm{s}$ : xylose conversion factor in ethanol; Y: percentage of ethanol production) were measured and calculated as described by Santos et al. [82].

\section{Analytical measurements}

The DNS method [83] was used for measurement of total reducing sugars. Analysis of xylose, furfural, and ethanol was performed using high-performance liquid chromatography as described by Rocha et al. [84]. Sugars, organic acids and fermentation products were quantified by Aminex HPX 87H (300 7.8 mm; Bio-Rad, Hercules, CA, USA) at $35{ }^{\circ} \mathrm{C}$ using $5 \mathrm{mM} \mathrm{H}_{2} \mathrm{SO}_{4}$ as the mobile phase at a flow rate of $0.6 \mathrm{~mL} / \mathrm{min}$. For the analysis of furfural and HMF, a reversed-phase HPLC equipped with an Acclaim $120 \mathrm{C} 18$ column $(150 \mathrm{~mm} \times 4.6 \mathrm{~mm}, 3 \mu \mathrm{m})$ and a single wavelength UV detector were used. The mobile phase was water-acetonitrile $1: 8(\mathrm{v} / \mathrm{v})$ with $1 \%$ acetic acid $(\mathrm{v} / \mathrm{v})$ at a flow rate of $0.8 \mathrm{~mL} / \mathrm{min}$. For greater accuracy and specificity, the samples were filtered through a Millex $22-\mu \mathrm{m}$ PVDF filter, and the filtrate was injected into the HPLC system.

SCB and PASB were characterized according to the methods of Sluiter et al. [85]. The lignocellulosic materials were air-dried to less than $10 \%(\mathrm{w} / \mathrm{w})$ of moisture content and then milled to obtain particle sizes of $0.12 \mathrm{~mm}$ in a knife mill (Pulverisette 19; Fritsch GmbH, Idar-Oberstein, Germany). After quantification of extracts (performed only for the raw bagasse) and ashes, the materials were milled again in a shear and impact mill (Pulverisette 14; Fritsch $\mathrm{GmbH}$ ), yielding a particle size of less than $0.5 \mathrm{~mm}$; these particles were used for analysis of structural carbohydrates (glucan, xylan, and arabinan) and soluble and insoluble lignin. The moisture content of the biomass was determined using an automatic infrared moisture analyzer (MA35; Sartorius Gmbh, Goettingen, Germany).

All analyses in this work were performed in triplicate, and Student's $t$ tests were performed. Results were considered significant when the $P$ value was less than 0.05 .

\section{Enzyme synergism and the role of ROS during glucan hydrolysis}

To evaluate CgAKR-1 synergism with glycoside hydrolases and the relationship with $\mathrm{H}_{2} \mathrm{O}_{2}$ generation, 1.0\% BG was hydrolyzed in $100 \mathrm{mM}$ phosphate buffer ( $\mathrm{pH}$ 5.7) in a total volume of $500 \mu \mathrm{L}$ at $30{ }^{\circ} \mathrm{C}$ and $1000 \mathrm{rpm}$ for $24 \mathrm{~h}$. Samples were collected at 1, 14, and $24 \mathrm{~h}$, and $100 \mathrm{ng}$ of each enzyme (CgAKR-1 and $C g$ GH9) and $200 \mathrm{nmol} / \mathrm{L}$ $\mathrm{NADPH}$ were combined as the "Mix". A commercial catalase $\left(\mathrm{H}_{2} \mathrm{O}_{2}\right.$ decomposer; cat. no. A22180; $1 \mathrm{U} / \mathrm{mL}$; Life Technologies) was used to evaluate the effects of ROS inhibitors on the DS. After hydrolysis, the $\mathrm{H}_{2} \mathrm{O}_{2}$ generation of each sample was measured with Amplex using $50 \mu \mathrm{L}$ of each reaction, and the total sugars were measured with the remaining sample. The analyses were performed in triplicate. No hydrolysis was detected by CgAKR-1 or NAPDH in the absence of endoglucanase. The DS for sugar release was calculated as follows: $(\mathrm{g} / \mathrm{L})$ of reducing sugar of $(\mathrm{CgGH} 9+$ enzyme $) /(\mathrm{g} / \mathrm{L})$ of reducing sugars of $\mathrm{CgGH} 9$, as described by Goldbeck [86].

\section{SCB hydrolysis and composition}

The SCBs were subjected to enzymatic saccharification with a commercially available enzyme preparation (Celluclast $1.5 \mathrm{~L}$; Novozymes) at $10 \mathrm{FPU} / \mathrm{g} \mathrm{SCB}$ and in combination with $0.5 \mathrm{mg}$ CgAKR-1 plus $6.25 \mathrm{mmol}$ $\mathrm{NAPDH} / \mathrm{g} \mathrm{SCB}$. The enzymatic hydrolysis was performed with $2 \%(\mathrm{w} / \mathrm{v}) \mathrm{SCB}$ in $100 \mathrm{mM}$ phosphate buffer (pH 5.7) at $30^{\circ} \mathrm{C}$. The reactions were carried out in $2-\mathrm{mL}$ Eppendorf tubes using a Thermomixer microplate incubator (Eppendorf, Germany). Samples were centrifuged at $10,000 \times g$ for $15 \mathrm{~min}$ (5418 Centrifuge; Eppendorf) and filtered (Sepak C18; Waters). The SCB was provided by Usina da Pedra (Serrana-SP). The material was collected in the 2013/14 crop and was mechanically harvested after the final milling before juice extraction. The phosphoric acid pretreatment (PASB) was described in detail in previous studies [61]. Denatured CgAKR-1 was used in all reactions lacking the enzyme. No hydrolysis was detected by CgAKR-1 or NAPDH in the absence of Celluclast. The analyses were performed in triplicate. The DS for sugar release was calculated as follows: $(\mathrm{g} / \mathrm{L})$ of reducing sugar of (Celluclast $+C g A K R-1) /(g / L)$ of reducing sugars of Celluclast, as described by Goldbeck [85].

\section{Additional file}

Additional file 1. Additional Figures S1-S7 and Table S1.

\footnotetext{
Abbreviations

C. gestroi: Coptotermes gestroi; CgAKR-1: Coptotermes gestroi aldo-keto reductase 1; S. stipitis: Scheffersomyces stipitis; $\mathrm{H}_{2} \mathrm{O}_{2}$ : hydrogen peroxide; HMF: hydroxymethylfurfural; PAD: pro-oxidant, antioxidant, and detoxification enzyme; ROS: reactive oxygen species; HPF: peroxynitrite sensor; NADPH: reduced form of nicotinamide adenine dinucleotide phosphate; $\cdot \mathrm{OH}$ : hydroxyl radical; CgGH9: termite Endoglucanase CgEG-1; BG: barley beta-glucan low viscosity; SCB: raw sugarcane bagasse; PASB: phosphoric acid-pretreated sugarcane bagasse; Mix: CgGH9 + CgAKR-1 + NADPH.
} 


\section{Authors' contributions}

RT designed and carried out all the experiments. JPLFC discovered and cloned the enzyme. FM supported the biochemical characterization. AS, SS, $\mathrm{Jl}$, and RR carried out the detoxifications and fermentations. SCR prepared the pretreated materials and performed the chemical composition analysis of process streams. MVL and BC worked on the enzyme 3D structure. RT, MVL, and ARLD drafted the manuscript. FMS conceived the study and participated in data interpretation. RT and FMS wrote the manuscript. All the authors read and approved the final manuscript.

\begin{abstract}
Author details
${ }^{1}$ Laboratório Nacional de Ciência e Tecnologia do Bioetanol (CTBE), Centro Nacional de Pesquisa em Energia e Materiais (CNPEM), Rua Giuseppe Máximo Scolfaro, no 10000 Campinas, SP, Brazil. ${ }^{2}$ Programa de Pós Graduação em Biociências e Tecnologia de Produtos Bioativos (BTPB)-Instituto de Biologia-CP 6109, Universidade Estadual de Campinas-UNICAMP, 13083-970 Campinas, SP, Brazil. ${ }^{3}$ Brazilian Biosciences National Laboratory (LNBio), from the Brazilian Center for Research in Energy and Materials (CNPEM), Campinas, Brazil. ${ }^{4}$ Department of Biochemistry and Tissue Biology, Institute of Biology, University of Campinas (UNICAMP), Campinas, SP, Brazil.
\end{abstract}

\section{Acknowledgements}

We gratefully acknowledge the provision of time at the analytical facilities and the sugarcane bagasse derivate provided by CTBE/CNPEM located in Campinas, Brazil. Additionally, we thank Ana Maria Costa Leonardo, Sílvio Roberto Consonni, and Marcelo Carazzolle for technical support.

\section{Competing interests}

The authors declare that they have no competing interests.

\section{Availability of data and materials}

The dataset supporting the conclusions of this article is included within the article and its additional files.

\section{Funding}

This work was financially supported by Grants from FAPESP (2014/20576-7; for RT; 2011/2977-3 for JPLFC; 2012/20549-4 for ARLD; 08/58037-9 for FMS; 2013/06336-0 for BC; 2014/04105-4 for MVL).

Received: 16 August 2016 Accepted: 14 December 2016

Published online: 03 January 2017

\section{References}

1. Segato F, Damásio AR, de Lucas RC, Squina FM, Prade RA. Genomics review of holocellulose deconstruction by aspergilli. Microbiol Mol Biol Rev. 2014;78:588-613.

2. Brune A. Symbiotic digestion of lignocellulose in termite guts. Nat Rev Microbiol. 2014;12:168-80.

3. Scharf ME, Tartar A. Termite digestomes as sources for novel lignocellulases. Biofuels Bioprod Biorefining. 2008;2:540-52.

4. Toledo Lima J, Costa-Leonardo AM. Subterranean termites (Isoptera: Rhinotermitidae): exploitation of equivalent food resources with different forms of placement. Insect Sci. 2012;19:412-8.

5. Franco Cairo JP, Leonardo FC, Alvarez TM, Ribeiro DA, Büchli F, CostaLeonardo AM, et al. Functional characterization and target discovery of glycoside hydrolases from the digestome of the lower termite Coptotermes gestroi. Biotechnol Biofuels. 2011;4:50.

6. Scharf ME, Karl ZJ, Sethi A, Boucias DG. Multiple levels of synergistic collaboration in termite lignocellulose digestion. PLOS ONE. 2011;6:e21709.

7. Sethi A, Slack JM, Kovaleva ES, Buchman GW, Scharf ME. Lignin-associated metagene expression in a lignocellulose-digesting termite. Insect Biochem Mol Biol. 2013;43:91-101.

8. Scharf ME, Boucias DG, Tartar A, Coy MR, Zhou X, Salem TIZ, et al. Termite enzymes and uses thereof for in vitro conversion of lignin-containing materials to fermentable products. Google Patents, US8445240 B2. 2013.

9. Silva J. JP, Carneiro LM, Roberto IC. Treatment of rice straw hemicellulosic hydrolysates with advanced oxidative processes: a new and promising detoxification method to improve the bioconversion process. Biotechnol Biofuels. 2013;6:23.

10. Ko JK, Um Y, Park YC, Seo JH, Kim KH. Compounds inhibiting the bioconversion of hydrothermally pretreated lignocellulose. Appl Microbiol Biotechnol. 2015;99:4201-12.

11. Jönsson LJ, Martín C. Pretreatment of lignocellulose: formation of inhibitory by-products and strategies for minimizing their effects. Bioresour Technol. 2016;199:103-12.

12. Field SJ, Ryden P, Wilson D, James SA, Roberts IN, Richardson DJ, et al. Identification of furfural resistant strains of Saccharomyces cerevisiae and Saccharomyces paradoxus from a collection of environmental and industrial isolates. Biotechnol Biofuels. 2015;8:33.

13. Liu ZL, Ma M, Song M. Evolutionarily engineered ethanologenic yeast detoxifies lignocellulosic biomass conversion inhibitors by reprogrammed pathways. Mol Genet Genomics. 2009;282:233-44.

14. Franden MA, Pienkos PT, Zhang M. Development of a high-throughput method to evaluate the impact of inhibitory compounds from lignocellulosic hydrolysates on the growth of Zymomonas mobilis. Biotechnol. 2009;144:259-67.

15. Liu X, Xu W, Mao L, Zhang C, Yan P, Xu Z, et al. Lignocellulosic ethanol production by starch-base industrial yeast under PEG detoxification. Sci Rep. 2016;6:20361.

16. Liu ZL, Moon J. A novel NADPH-dependent aldehyde reductase gene from Saccharomyces cerevisiae NRRL Y-12632 involved in the detoxification of aldehyde inhibitors derived from lignocellulosic biomass conversion. Gene. 2009:446:1-10.

17. Gutiérrez T, Ingram LO, Preston JF. Purification and characterization of a furfural reductase (FFR) from Escherichia coli strain LYO1-an enzyme important in the detoxification of furfural during ethanol production. J Biotechnol. 2006;121:154-64.

18. Peciulyte A, Karlström K, Larsson PT, Olsson L. Impact of the supramolecular structure of cellulose on the efficiency of enzymatic hydrolysis. Biotechnol Biofuels. 2015:8:56.

19. Dimarogona M, Topakas E, Christakopoulos P. Recalcitrant polysaccharide degradation by novel oxidative biocatalysts. Appl Microbiol Biotechnol. 2013;97:8455-65

20. Dashtban M, Schraft H, Qin W. Fungal bioconversion of lignocellulosic residues; opportunities \& perspectives. Int J Biol Sci. 2009;5:578-95.

21. Engel P, Moran NA. The gut microbiota of insects-diversity in structure and function. FEMS Microbiol Rev. 2013;37:699-735.

22. Vu AT, Nguyen NC, Leadbetter J. Iron reduction in the metal-rich guts of wood-feeding termites. Geobiology. 2004;2:239-47.

23. Li H, Lu J, Mo J. Physiochemical lignocellulose modification by the Formosan subterranean termite Coptotermes formosanus Shiraki (Isoptera: Rhinotermitidae) and its potential uses in the production of biofuels. BioResources. 2012;7:675-85.

24. Ke J, Chen S. Biological pretreatment of biomass in wood-feeding termites. In: Sun J, Ding S, Peterson JD, editors. Biological conversion of biomass for fuels and chemicals: explorations from natural utilization systems. Cambridge: Royal Society of Chemistry; 2012. p. 177-94.

25. Rashid GM, Taylor CR, Liu Y, Zhang X, Rea D, Fülöp V, et al. Identification of manganese superoxide dismutase from Sphingobacterium sp. T2 as a novel bacterial enzyme for lignin oxidation. ACS Chem Biol. 2015;10:2286-94.

26. Franco Cairo JP, Carazzolle M, Leonardo F, Mofatto L, Brenelli LB, Gonçalves TA, et al. Expanding the knowledge on lignocellulolytic and redox enzymes of worker and soldier castes from the lower termite Coptotermes gestroi. Front Microbiol. 2016;7:1518.

27. Scharf M, Sethi A. Novel lignases and aldo-keto reductases for conversion of lignin-containing materials to fermentable products. Google Patents, WO 2013126230 A1. 2013.

28. Penning TM. The aldo-keto reductases (AKRs): overview. Chem Biol Interact. $2015 ; 234: 236-46$.

29. Feldman D, Kowbel DJ, Glass NL, Yarden O, Hadar Y. Detoxification of 5-hydroxymethylfurfural by the Pleurotus ostreatus lignolytic enzymes aryl alcohol oxidase and dehydrogenase. Biotechnol Biofuels. 2015;8:63.

30. Barski OA, Tipparaju SM, Bhatnagar A. The aldo-keto reductase superfamily and its role in drug metabolism and detoxification. Drug Metab Rev. 2008;40:553-624

31. Itoh N, Asako H, Banno K, Makino Y, Shinohara M, Dairi T, et al. Purification and characterization of NADPH-dependent aldo-keto reductase 
specific for beta-keto esters from Penicillium citrinum, and production of methyl (S)-4-bromo-3-hydroxybutyrate. Appl Microbiol Biotechnol. 2004;66:53-62.

32. Zhang W, Geng A. Improved ethanol production by a xylose-fermenting recombinant yeast strain constructed through a modified genome shuffling method. Biotechnol Biofuels. 2012;5:46.

33. Tartar A, Wheeler MM, Zhou X, Coy MR, Boucias DG, Scharf ME. Parallel metatranscriptome analyses of host and symbiont gene expression in the gut of the termite Reticulitermes flavipes. Biotechnol Biofuels. 2009;2:25.

34. Raychoudhury R, Sen R, Cai Y, Sun Y, Lietze VU, Boucias DG, et al. Comparative metatranscriptomic signatures of wood and paper feeding in the gut of the termite Reticulitermes flavipes (Isoptera: Rhinotermitidae). Insect Mol Biol. 2013;22:155-71.

35. Hyndman D, Bauman DR, Heredia W, Penning TM. The aldo-keto reductase superfamily homepage. Chem Biol Interact. 2003;143-144:621-31.

36. Zhou Y, Mo J, Chen K, Xu Q. Isolation and characterization of P450 gene from the Formosan subterranean termite, Coptotermes formosanus (Isoptera: Rhinotermitidae). Sociobiology. 2012;59:1121-36.

37. Stewart AD, Anand RR, Laird JS, Verrall M, Ryan CG, de Jonge MD, et al. Distribution of metals in the termite Tumulitermes tumuli (Froggatt): two types of Malpighian tubule concretion host Zn and Ca mutually exclusively. PLOS ONE. 2011;6:e27578.

38. Nakamura K, Kondo S, Kawai Y, Nakajima N, Ohno A. Amino acid sequence and characterization of aldo-keto reductase from bakers'yeast. Biosci Biotechnol Biochem. 1997;61:375-7.

39. Petrash JM, Srivastava SK. Purification and properties of human liver aldehyde reductases. Biochim Biophys Acta. 1982;707:105-14.

40. Davidson WS, Flynn TG. Kinetics and mechanism of action of aldehyde reductase from pig kidney. Biochem J. 1979;177:595-601.

41. Flowers-Geary L, Harvey RG, Penning TM. Examination of diols and diol epoxides of polycyclic aromatic hydrocarbons as substrates for rat liver dihydrodiol dehydrogenase. Chem Res Toxicol. 1992;5:576-83.

42. Penning TM. Human aldo-keto reductases and the metabolic activation of polycyclic aromatic hydrocarbons. Chem Res Toxicol. 2014;27:1901-17.

43. Mayat NS, Nikolayeva II, Golova OP. Mechanism of the oxidative degradation of cellulose in alkaline media-II. Mechanism of the oxidation of cellulose in an alkaline medium by oxygen. Polym Sci USSR. 1964;6:1875-82.

44. Knill CJ, Kennedy JF. Degradation of cellulose under alkaline conditions. Carbohydr Polym. 2003;51:281-300.

45. Arantes $\mathrm{V}$, Jellison J, Goodell B. Peculiarities of brown-rot fungi and biochemical Fenton reaction with regard to their potential as a model for bioprocessing biomass. Appl Microbiol Biotechnol. 2012;94:323-38.

46. Sanli G, Dudley Jl, Blaber M. Structural biology of the aldo-keto reductase family of enzymes: catalysis and cofactor binding. Cell Biochem Biophys. 2003;38:79-101

47. Jez JM, Bennett MJ, Schlegel BP, Lewis M, Penning TM. Comparative anatomy of the aldo-keto reductase superfamily. Biochem J. 1997;326:625-36.

48. Liu ZL, Moon J, Andersh BJ, Slininger PJ, Weber S. Multiple gene-mediated NAD(P)H-dependent aldehyde reduction is a mechanism of in situ detoxification of furfural and 5-hydroxymethylfurfural by Saccharomyces cerevisiae. Appl Microbiol Biotechnol. 2008;81:743-53.

49. Wilson DK, Bohren KM, Gabbay KH, Quiocho FA. An unlikely sugar substrate site in the $1.65 \mathrm{~A}$ structure of the human aldose reductase holoenzyme implicated in diabetic complications. Science. 1992;257:81-4.

50. Wahlbom CF, Hahn-Hägerdal B. Furfural, 5-hydroxymethyl furfural, and acetoin act as external electron acceptors during anaerobic fermentation of xylose in recombinant Saccharomyces cerevisiae. Biotechnol Bioeng. 2002;78:172-8.

51. Taherzadeh MJ, Karimi K. Fermentation inhibitors in ethanol processes and different strategies to reduce their effects. In: Pandey A, Larroche C, Ricke SC, Dussap CG, Gnansounou E, editors. Biofuels. Oxford: Elsevier Inc.; 2011. p. 287-311.

52. Jurado M, Prieto A, Martínez-Alcalá A, Martínez AT, Martínez MJ. Laccase detoxification of steam-exploded wheat straw for second generation bioethanol. Bioresour Technol. 2009;100:6378-84.

53. Jönsson LJ, Palmqvist E, Nilvebrant NO, Hahn-Hägerdal B. Detoxification of wood hydrolysates with laccase and peroxidase from the white-rot fungus Trametes versicolor. Appl Microbiol Biotechnol. 1998;49:691-7.

54. Tanaka H, Itakura S, Enoki A. Hydroxyl radical generation by an extracellular low-molecular-weight substance and phenol oxidase activity during wood degradation by the white-rot basidiomycete Trametes versicolor. J Biotechnol. 1999;75:57-70.

55. Rabelo SC, Rossell CEV, Rocha GJM, Zacchi G. Enhancement of the enzymatic digestibility of sugarcane bagasse by steam pretreatment impregnated with hydrogen peroxide. Biotechnol Progress. 2012;28:1207-17.

56. Franco Cairo JPL, Oliveira LC, Uchima CA, Alvarez TM, Citadini AP, Cota $J$, et al. Deciphering the synergism of endogenous glycoside hydrolase families 1 and 9 from Coptotermes gestroi. Insect Biochem Mol Biol. 2013;43:970-81.

57. Wei D, Houtman CJ, Kapich AN, Hunt CG, Cullen D, Hammel KE. Laccase and its role in production of extracellular reactive oxygen species during wood decay by the brown rot basidiomycete Postia placenta. Appl Environ Microbiol. 2010;76:2091-7.

58. Grissa I, Bidard F, Grognet P, Grossetete S, Silar P. The Nox/Ferric reductase/ Ferric reductase-like families of Eumycetes. Fungal Biol. 2010;1 14:766-77.

59. Zámocký M, Hallberg M, Ludwig R, Divne C, Haltrich D. Ancestral gene fusion in cellobiose dehydrogenases reflects a specific evolution of GMC oxidoreductases in fungi. Gene. 2004;338:1-14.

60. Duan J, Kasper DL. Oxidative depolymerization of polysaccharides by reactive oxygen/nitrogen species. Glycobiology. 2011;21:401-9.

61. de Vasconcelos SM, Santos AM, Rocha GJ, Souto-Maior AM. Diluted phosphoric acid pretreatment for production of fermentable sugars in a sugarcane-based biorefinery. Bioresour Technol. 2013;135:46-52.

62. Gouveia ER, Nascimento RT, Souto-Maior AM, Rocha GJM. Validação de metodologia para a caracterização química de bagaço de cana-deaçúcar. Quim Nova. 2009;32:1500-3.

63. Wang Q, Wang Z, Shen F, Hu J, Sun F, Lin L, et al. Pretreating lignocellulosic biomass by the concentrated phosphoric acid plus hydrogen peroxide (PHP) for enzymatic hydrolysis: evaluating the pretreatment flexibility on feedstocks and particle sizes. Bioresour Technol. 2014;166:420-8.

64. Phillips CM, Beeson WT, Cate JH, Marletta MA. Cellobiose dehydrogenase and a copper-dependent polysaccharide monooxygenase potentiate cellulose degradation by Neurospora crassa. ACS Chem Biol. 2011;6:1399-406

65. Saitou N, Nei M. The neighbor-joining method: a new method for reconstructing phylogenetic trees. Mol Biol Evol. 1987;4:406-25.

66. Jones DT, Taylor WR, Thornton JM. The rapid generation of mutation data matrices from protein sequences. Comput Appl Biosci. 1992;8:275-82.

67. Tamura K, Stecher G, Peterson D, Filipski A, Kumar S. MEGA6: molecular evolutionary genetics analysis version 6.0. Mol Biol Evol. 2013;30:2725-9.

68. Mandelli F, Brenelli LB, Almeida RF, Goldbeck R, Wolf LD, Hoffmam ZB, et al. Simultaneous production of xylooligosaccharides and antioxidant compounds from sugarcane bagasse via enzymatic hydrolysis. Ind Crops Prod. 2014;52:770-5.

69. Kabsch W. XDS. Acta Crystallogr D Biol Crystallogr. 2010;66:125-32.

70. Evans PR. An introduction to data reduction: space-group determination, scaling and intensity statistics. Acta Crystallogr D Biol Crystallogr. 2011;67:282-92.

71. McCoy AJ, Grosse-Kunstleve RW, Adams PD, Winn MD, Storoni LC, Read RJ. Phaser crystallographic software. J Appl Crystallogr. 2007;40:658-74.

72. Emsley P, Lohkamp B, Scott WG, Cowtan K. Features and development of Coot. Acta Crystallogr D Biol Crystallogr. 2010;66:486-501.

73. Chen Z, Friedland GD, Pereira JH, Reveco SA, Chan R, Park Jl, et al. racing determinants of dual substrate specificity in glycoside hydrolase family 5 . J Biol Chem. 2012;287:25335-43.

74. Chen VB, Arendall WB 3rd, Headd JJ, Keedy DA, Immormino RM, Kapral GJ, et al. MolProbity: all-atom structure validation for macromolecular crystallography. Acta Crystallogr D Biol Crystallogr. 2010;66:12-21.

75. Price DR, Du J, Dinsmore A, Gatehouse JA. Molecular cloning and immunolocalization of a diuretic hormone receptor in rice brown planthopper (Nilaparvata lugens). Insect Mol Biol. 2004;13:469-80.

76. Watabe S, Sakamoto Y, Morikawa M, Okada R, Miura T, Ito E. Highly sensitive determination of hydrogen peroxide and glucose by fluorescence correlation spectroscopy. PLoS ONE. 2011;6:e22955.

77. Setsukinai K, Urano Y, Kakinuma K, Majima HJ, Nagano T. Development of novel fluorescence probes that can reliably detect reactive oxygen species and distinguish specific species. J Biol Chem. 2003;278:3170-5.

78. Santoro DCJ, Assis T, Dionisio SR, lenczak JL, Rabelo SC. Scaling up dilute sulfuric acid pretreatment for sugarcane bagasse bioethanol production. Poster presentation, 37th SBFC, San Diego; 2015. 
79. Dussán KJ, Silva DV, Perez VH, da Silva SS. Evaluation of oxygen availability on ethanol production from sugarcane bagasse hydrolysate in a batch bioreactor using two strains of xylose-fermenting yeast. Renew Energ 2016:87:703-10.

80. Scordia D, Cosentino SL, Lee JW, Jeffries TW. Bioconversion of giant reed (Arundo donax L.) hemicellulose hydrolysate to ethanol by Scheffersomyces stipitis CBS6054. Biomas Bioenerg. 2012;39:296-305.

81. Dussán KJ, Silva DDV, Perez VH, da Silva SS. Evaluation of oxygen availability on ethanol production from sugarcane bagasse hydrolysate in a batch bioreactor using two strains of xylose-fermenting yeast. Renew Energy. 2016:87:703-10

82. Santos SC, Silva de Sousa A, Rodrigues Dionísio S, Tramontina R, Ruller R, Squina FM, Vaz Rossell CE, da Costa AC, lenczak JL. Bioethanol production by recycled Scheffersomyces stipitis in sequential batch fermentations with high cell density using xylose and glucose mixture. Bioresour Technol. 2016;219:319-29.
83. Miller GL. Use of dinitrosalicylic acid reagent for determination of reducing sugar. Anal Chem. 1959:31:426-8.

84. Rocha GJM, Gonçalves AR, Oliveira BR, Olivares EG, Rossell CEV. Steam explosion pretreatment reproduction and alkaline delignification reactions performed on a pilot scale with sugarcane bagasse for bioethanol production. Ind Crops Prod. 2012;35:274-9.

85. Sluiter JB, Chum H, Gomes AC, Tavares RAP, Azevedo V, Pimenta MTB, et al. Evaluation of Brazilian sugarcane bagasse characterization: an interlaboratory comparison study. J AOAC Int. 2016;99:579-85.

86. Goldbeck R, Damásio ARL, Gonçalves TA, Machado CB, Paixão DA, Wolf $L D$, et al. Development of hemicellulolytic enzyme mixtures for plant biomass deconstruction on target biotechnological applications. Appl Microbiol Biotechnol. 2014;98:8513-25.

\section{Submit your next manuscript to BioMed Central and we will help you at every step:}

- We accept pre-submission inquiries

- Our selector tool helps you to find the most relevant journal

- We provide round the clock customer support

- Convenient online submission

- Thorough peer review

- Inclusion in PubMed and all major indexing services

- Maximum visibility for your research

Submit your manuscript at www.biomedcentral.com/submit 